\title{
近軸散乱光の出射特性に関する基礎的検討
}

$\begin{array}{lllll}\text { 学生員 木戸岡 智志 (北海道工業大学) } & \text { 非会員 } & \text { 北間 } & \text { 正崇 (北海道工業大学) } \\ \text { 正 員 三澤 } & \text { 顕次 } & \text { (北海道工業大学) } & \text { 非会員 } & \text { 有澤 } \\ \text { 準二(北海道工業大学) }\end{array}$

\section{Fundamental study on emission characteristics of near-axis scattered light}

Satoshi KIDOOKA, Student-member, Masataka KITAMA, Non-member, Kenji MISAWA, Member, Junji ARISAWA, Non-member (Hokkaido Institute of Technology), Koichi SHIMIZU, Member (Hokkaido University)

Characteristics of near-axis scattered light were investigated to get optical imaging of biological body. In the Monte Carlo simulation and time-resolved measurement, shapes of light pulse emitted from a tissue-like scattering object were analyzed. The near-axis scattered light was detectable in terms of its intensity and angular characteristic.

キーワード：光 C T, 散乱, 光計测, 生体, 連続光

\section{1.はじめに}

近年, 近赤外領域(波長700〜 1,200 nm)の光を用いて生体 組織の譏能情報を取得する可能性が広く認められ, 光 C T (光による生体断層イメージング)の実現などに向け, 各国で 活発な研究が行われている(1)，光 C Tを実現する上で大き な障害となっているのは, 生体組織における強い光散乱の 影響である。この影響を㧕制し生体透過光を検出するた め, 我々は入射ビーム光の光軸に沿って散乱された近軸散 乱光に着目し，その特性をシミュレーションや実験 ${ }^{(2)} に よ$ り調べてきた.しかしこの近軸散乱光の挙動や諸特性につ いては，原理的に説明はされているものの，いまだ詳細が 明らかにされていない。

本論文では, 近軸散乱光の分離検出の可能性を調べるた め, 時間分解手法を用いて散乱体透過光の出射特性につい て実験的検討を行った.

\section{2. 近軸散乱光}

生体租織は光学的に不均質であり, 強い散乱性を示す. この散乱の平均自由行程は $1 \mathrm{~mm}$ 程度であり, $1 \mathrm{~cm}$ 厚みの組 織でも，散乱を受けない成分の検出は実用上困難である.

生体組織に入射されたビーム光は，内部で散乱され種々 の程路を通り，そのほとんどが光軸から大きくはずれて出 射する。ただし，生体組織は強い前方散乱性を有している ことから，一部の光は入射ビームの光軸に沿って伝搬し， 光軸方向に出射する．このように，散乱を繰り返しながら も入射光軸にまつわりつくように伝般し, 出射してくる散 乱光を近軸散乱光(snake photonと俗称されることもある) と眯ぶ.

近軸散乱光を他の散乱光から分離噧出することが可能に なれば，X線 C Tと同様のアルゴリズムにより，散乱の影 響を抑制しつつ散乱体中の吸光度分布のイメージングが可 能になると考えられる。しかし近軸散乱光については，他
の散乱光から分雕検出できるだけの強度を持つか, またど のような特性を有しているかについてすら，これまで報告 例は見当たらない。本研究では，散乱体加らの出射光に， 既存技術で分離検出可能な程度近軸散乱光成分が含まれる かどうかについて明らかにすることを試みた。

\section{3. シミュレーション}

まずモンテカルロ法に基づくシミュレーションにより， 近軸散乱光の時間分解波形を求めた。シミュレーションの 詳細については，文献 ${ }^{(3)(4)}$ を参照されたい. 図 1 に対象とし たモデルの模式図を, 図 2 にそれらから得られた出射散乱 光の時間分解波形を示す。なお, シミュレーションにおい ては，結果の解釉を容易にするためインパルス光入射(入射 パルス光の時間幅無限小)を仮定している.

図2の波形bに見られるように，散乱を释ない透過光成分 の予想到達時間(図中矢印)から明らかに遅れて近軸散乱光成 分が検出される.また図 $2 \mathbf{a}, \mathbf{b} の$ 比較から，近軸以外の散乱 光成分を含む場合(全散乱光と呼ぶ)に比べ, 近軸散乱光は, 遅い時刻の強度の落ち込みが顕著であることがわかる。

\section{4. 計测}

シミュレーションで得られた近軸散乱光の特性をもと に, 出射散乱光中に検出可能な程度近軸散乱光成分が存在 するかどうかを検証する実験を行った.

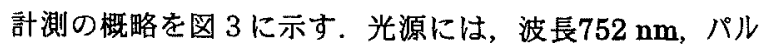

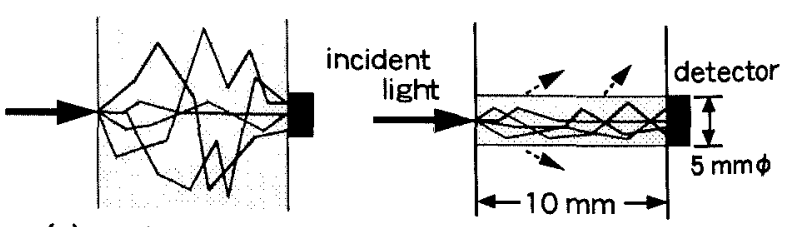

(a) whole scattering

(b) near-axis scattering

凶1：ミュレーションモデル

Fig. 1. Model of simulation 


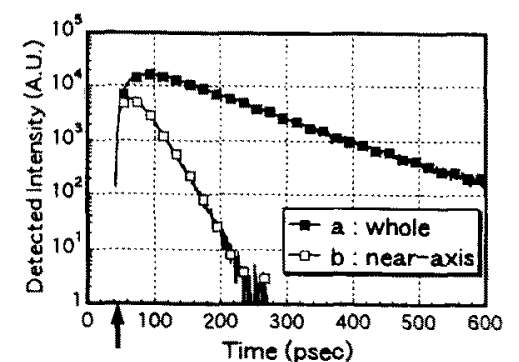

因 2 シミュレーション結果

Fig. 2. Result of simulation

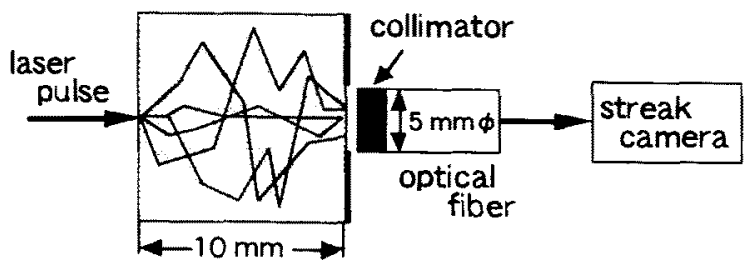

図 3 計測試料

Fig. 3. Sample of measurement

又半值幅 $38 \mathrm{ps}$ ，ピーク出力約 $25 \mathrm{~mW}$ のレーザダイオードを 使用した．光源から出射した光は，コリメートレンズつき 光ファイバによりビーム光として試料に照射される。試料 によって散乱された光は，レンズとピンホールにより目的 の受光角に制限された後，コア径 $200 \mu \mathbf{m}$ のマルチモード光 ファイバを介してストリークカメラ(時間分解能 $15 \mathrm{psec}$ )に ス力され，時間分解波形として処理される。

散乱体試料には，内壁間隔 $10 \mathrm{~mm}$ のアクリル水畨の内部

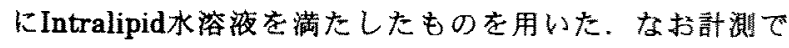
牥，散乱俰数および受光角を変化させた際の時間分解波形 を取得した。

\section{5. 計測結果および考察}

計汼した受光パルス波形は，近軸散乱以外の成分と近軸 散乱成分の両者を含んでいる。近軸散乱光は出射面におい ても光軸に治って出射するので，受光角を小さくすること により，受光信号に占めるその割合が增加すると考えられ る，そこで，受光角を小さくした場合の出射パルス波形の 変化を調べた。

散乱体の光学特性证，散乱体の光学的濃度optical density (OD $=\mu s^{\prime} * \mathrm{~d}: こ こ て ゙ \mu s^{\prime}$ 恃等価散乱係数, d㥇何学的厚 夕)に大きく低存する． $O D=10\left(\mu \mathrm{s}^{\prime}=1.0 \mathrm{~mm}^{-1}, \mathrm{~d}=10 \mathrm{~mm}\right)$ の 場合の結果を図 4 に示す。ここでは出射パルスの形状を比 較するため，得られた時間分解波形を最大振幅で規格化し て示している. 受光角の飭囲を小さく( には大きな変化㹥見られない，つまり，近軸散乱以外の散 乱光強度が近軸成分を大きく上回っており, 近軸散乱光成 分の変化が検出できていない. つまりこの $\mathrm{OD}=10 に$ 対して 本集缸置の感度や分解能では，出射方向の違いに基づく 近軸散乱光の分嚄検出は，不可能と考えられる.しかし， 図 5 に示す $O D=7\left(\mu \mathrm{s}^{\prime}=0.7 \mathrm{~mm}^{-1}, \mathrm{~d}=10 \mathrm{~mm}\right)$ の結果では，受

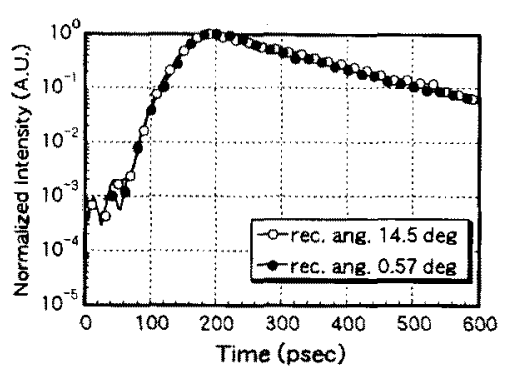

図 4 出射パルス波形 $(O D=10)$

Fig. 4. Measured emission pulse ( $O D=10$ )

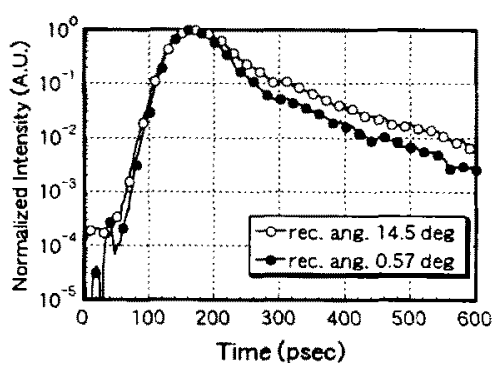

図 5 甘射パルス波形 $(\mathrm{OD}=7)$

Fig. 5. Measured emission pulse $(O D=7)$

光角の範囲を小さくすることにより，波形のピーク以降の 強度が明らかに减少するのがわかる。つまりこの結果は， $\mathrm{OD}=7$ 程度ならば, 受光信号に上める近軸散乱光成分の变化 が検出可能なレベルであることを示している.

これらの結果より，本計測条件下で住，近軸散乱光が他 の散乱光成分から分離検出できる強度と特性を有してい ることがわかった。この結果は，生体の等価散乱保数を $1.0 \mathrm{~mm}^{-1}$ とすると, 少なくとも7 $\mathrm{mm}$ 程度の厚加の生体組織 においては，比較的単純な受光角の違いだけでも，近軸散 乱光の分離検出が可能なことを示㖫している.

\section{6.おわりに}

シミュレーションと実駼により，時間分解手法を用いて 近軸散乱光の出射特性を解析した，解析をとおし，特定条 件下ではあるが，出射角の違いに基づき近軸散乱光を分離 検出できる可能性が奏鲜された。

\section{謝辞}

本研究の一部は，第 7 回(社)照明学会研究・教育助成なら びに文部省科学研究費(09780810)により行われた。

(平成 10 年 10 月 29 日受付)

\section{文献}

(1) B. Chance and R. R. Alfano, ed., "Optical Tomography, photon migration, and spectroscopy of tissue and model media - theory, human studies and instrumentation -," Proc. SPIE, 2389 (1995)

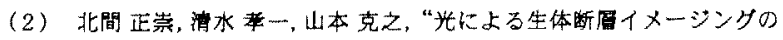

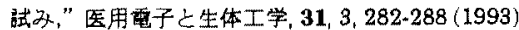

(3) P. van der Zee and D. T. Delpy, "Simulation of the point spread function for light in tissue by a Monte Carlo method," Adv. Exp. Med, Biol., 215, 179-191 (1986)

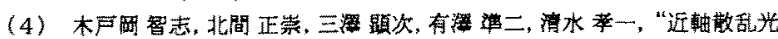

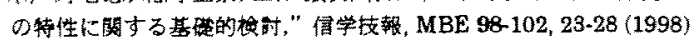

